\title{
Nutrient component analyses of selected wild edible plants from Hamirpur district of Himachal Pradesh, India: An evaluation for future food
}

\section{Ram Chand Bhatti}

Panjab University Faculty of Science

\section{Rupinder Kaur}

Panjab University Faculty of Science

\section{Abhishek Kumar}

Panjab University Faculty of Science

\section{Viney Kumar}

Panjab University Faculty of Science

\section{Siril Singh}

Panjab University Faculty of Science

\section{Pardeep Kumar}

Panjab University Faculty of Science

\section{Sheenu Sharma}

Panjab University Faculty of Science

\section{Nirmala Chongtham}

Panjab University Faculty of Science

Anand Narain Singh ( $\nabla$ dranand1212@gmail.com )

Panjab University Chandigarh https://orcid.org/0000-0002-0148-8680

\section{Research}

Keywords: Future food, Wild edible plant, Nutrient component, Forest, Indices

Posted Date: January 14th, 2021

DOI: https://doi.org/10.21203/rs.3.rs-143807/v1

License: (c) (1) This work is licensed under a Creative Commons Attribution 4.0 International License. Read Full License 


\section{Abstract \\ Background}

Indigenous people of any particular region use various wild plants for their food, medicines, and other economic products. Many of these wild plants have been documented for their utilization as future foods and medicines based on these people's information. However, information about the nutrient components of many wild edible plants has yet to be scientifically tested. Therefore, this study evaluated the nutrient components of selected wild edible plants.

\section{Methods}

A total of 21 species were selected for nutrient and mineral analyses from a total of 90 wild edible plants reported during the survey of 1720 households. Based on the reported edible use, different plant parts of each species were evaluated for their carbohydrate, protein, fat, vitamin, and mineral contents. The obtained data were then analyzed using various quantitative indices to assess the selected wild edible plant's efficacy.

\section{Results}

It was found that nutrient content considerably varied among all the selected species. Among the selected plant species, Digera muricata has the richest protein content, the tuber of Dioscorea $s p$. has plenty of carbohydrate content, and Dioscorea bulbifera has the highest fat content. Similarly, Spondias

pinnata and Boerhavia diffusa were rich sources of vitamin C and vitamin E, respectively. Digera muricata was found to be promising future food based on overall nutrient composition.

\section{Conclusions}

Several traditionally used wild edible plants can have surprisingly higher nutritional contents. These plants can offer a basis for developing dietary supplements and nutraceuticals on a commercial scale. Thus, scientific evaluation and validation of such underutilized plants and their products may prove an alternative future food for malnutrition people.

\section{Background}

Each edible plant do not contain all essential nutrients required for human health in sufficient amounts to meet the daily dietary need in a single serving. For example, leafy vegetables are good sources of most minerals and vitamins but have fewer nutrients with respect to proteins and carbohydrates. Similarly, fruits and tubers are rich in carbohydrates, vitamins, carotenoids but generally minor in proteins and minerals, whereas seeds are rich in proteins, carbohydrates, and lipids. To meet all the required nutrients, 
a person should take a balanced healthy diet of seeds, fruits, vegetables, and leaves. Unfortunately, many people do not consume a sufficient amount of diet from staple foods in developing nations. As a result, about three billion children and women are at risk of malnutrition (33\% of world's population). In most developing countries, people do not get sufficient food supply, and the people who get sufficient food are not getting healthy food [1, 2]. Due to changing lifestyles and food habits, people depend more on readily available processed food, which is mostly deficient in nutrient contents and causes malnutrition, especially in children [3-5]. Thus, there is a need to find new alternative plants that can prove a good source of nutrient-rich food for the future [4-7].

In developing countries, wild plants' consumption is usually restricted to local indigenous people because they cannot afford cultivated commercial fruits and vegetables. In India, wild plants play a significant role in food and nutrient security for tribal and poor people $[5,8,9]$. Some wild plants have been reported to have good nutritional value than commercialized fruits and vegetables [10]. These plants' higher nutritive value imparts potentially positive effects on human health by lowering the risk of many diseases such as diabetes, cancer, and heart-related disorders. Therefore, these plants have gained the attention of food scientists, industrialists, farmers, and other stakeholders. The dietitians are working on a new base to develop food, medicine, and supplements for undernourished people. Nowadays, the private sector is also coming forward to promote these underutilized plants for future food. [11-15]. An inventory of wild food resources and nutrient analysis for scientific validation can establish the substitute crops for the domestic and cultivated species, which will help select important and valuable wild plant species.

About 1532 edible wild food species are reported in India [16], in which over 675 species are known only from the Himalayan region $[4,5,17]$. Further, it is estimated that about 800 species are consumed as wild edible species, mainly by the tribal people. Knowledge of these plant species will help explore new possibilities in further research work in food and other purposes. They may provide employment and economic benefits to the people of rural areas. Hence, these underutilized plants are put into use as food but now are being projected as healthy food [18-22].

Furthermore, fruits and vegetables also contain a vast and multifaceted array of bioactive secondary compounds that promise to promote good health and protect against many diseases $[4,5,23]$. To ensure an adequate dietary intake of all essential nutrients and increase the consumption of various healthpromoting compounds, researchers have been interested in improving plants' nutritional quality concerning nutrient composition and concentration [23].

The selected study area Himachal Pradesh is endowed with various climatic conditions; therefore, different kinds of tropical, subtropical, and temperate plants reside in the proximity of this Himalayan region. Due to the variation of climatic conditions, it has a rich diversity of wild fruits, leafy vegetables, and tubers enjoyed by the local people since time immemorial. Major economic wild plants such as Aegle marmelos, Spondias pinnata, Phyllanthus emblica, Punica granatum, Pyrus pashia, Citrus sp., Ficus sp., Amaranthus sp., Chenopodium sp., Dioscorea sp., Colocasia macrorrhiza, Colocasia indica, Colocasia esculenta, Moringa oleifera, Ceropegia sp. and Bambusa sp. are found in the study area. However, future 
utilization of these wild fruit, vegetable, and tuber plants are unexplored as people are unaware of their nutritive values. Moreover, many plants face the threat of extinction due to population pressure and destruction of habitat (Aegle marmelos, Spondias pinnata, Moringa oleifera, Ceropegia, etc.). Thus, the present investigation is done on the screening and evaluating the essential underutilized plants for nutrient component analyses.

In this paper, we have evaluated the nutrient components and the role of plant foods play in human nutrition and health of 21 wild plants selected from the study area, and the following questions have been answered:

1. Which plants are rich in protein and carbohydrates and can be incorporated into a regular diet?

2. Which plants are rich in vitamin content and can be beneficial in vitamin deficiencies?

3. Which plants are a good source of iron and calcium, and other minerals to be useful in anemic and healthy bones?

For this purpose, a systematic study was conducted, and information on plants was collected from local people of the Hamirpur district of Himachal Pradesh. Documentation of plant uses was followed by nutrient analyses for amino acid, protein, carbohydrate, starch, fat, vitamin, dietary fiber, phytosterol, total phenol, and mineral analysis ( $\mathrm{Ca}, \mathrm{K}, \mathrm{Na}, \mathrm{Mg}, \mathrm{S}, \mathrm{Si}, \mathrm{Ni}, \mathrm{Cu}, \mathrm{Fe}, \mathrm{Mn}$, etc.) and physical parameters such as moisture and ash content.

\section{Methods}

\section{Study area and field survey}

Hamirpur is a south-western district of Himachal Pradesh, which lies between $76^{\circ} 17^{\prime} 50^{\prime \prime}$ to $76^{\circ} 43^{\prime} 42^{\prime \prime}$ east longitudes and $31^{\circ} 24^{\prime} 48^{\prime \prime}$ to $31^{\circ} 53^{\prime} 35^{\prime \prime}$ north latitudes. This district covers an area of $1118 \mathrm{~km}^{2}$, and its elevation varies from 400 to 1100 meters. The climate is mainly sub-tropical with an average annual rainfall of about $1520 \mathrm{~mm}$, where maximum rainfall occurs in July to September and minimum in April to June. The annual mean temperature ranges between $20^{\circ} \mathrm{C}$ to $25^{\circ} \mathrm{C}$ in most of the district's parts.

A total of 1720 informants (1069 males and 651 females) were face to face interviewed to gather information about plants regarding food and medicinal value. Out of these, 472 informants provided information about food plants. Based on the informant's consensus, a total of 90 plant species were found as edible, of which 21 plant species were selected for nutrient analysis based on the informant's perceptions, availability, and uses. Chemical and nutrient analyses were conducted to see the efficacy of these species based on the nutrient richness and the relative nutrient value of each selected species to determine these plant species' significance.

\section{Sample collection}

Field trips of 3-4 days were made in different seasons to collect the samples of screened plants used for edible purposes. The aboveground plant parts were manually hand-picked, and the underground parts 
were dug out using a digger and spade with assistance from the local people. The collected plant samples were kept in separate thermocol (polystyrene) boxes to retain freshness during transportation. Then samples were brought to the laboratory for nutrient and mineral analysis.

\section{Biochemical analysis}

The biochemical analysis included the estimation of nutritional and bioactive content of edible parts of the selected plant species using previously described standard methods in each case: free amino acids [24], proteins [25], carbohydrates [26], starch [27], fats [28], dietary fiber and its components [29], vitamin C [30], vitamin E [31], ash content [32], phenols [33] and phytosterols [34]. Mineral elements were analyzed through wavelength dispersion X-ray fluorescence (WDXRF). Overall, this study estimated 28 nutrient components, including ten minerals, ash, and moisture content.

\section{Quantitative analysis}

The relative importance of selected plant species was assessed using specific quantitative indices were developed and employed (Table 1). Firstly, the relative nutrient content $\left(R N_{i j}\right)$ of $j$ th nutrient in $i$ th species was calculated as the ratio of $j$ th nutrient content in ith species to all species' total $j$ th nutrient content. This relative content was then converted to a percentage by multiplying with 100 .

Table 1 Indices derived for the nutrient component analyses 
Relative Nutrient Content

$$
R N_{i j}=\left(\frac{N_{i j}}{\sum_{i=1}^{n} N_{i j}}\right) \times 100
$$

Nutrient $j$ as of total nutrients

$$
N T N_{i j}=\left(\frac{N_{i j}}{\sum_{j=1}^{7} N_{i j}}\right) \times 100[j=A A, C, F, P r, S t, V C, V E]
$$

Relative Nutrient Value Index

$$
R N V I_{i}=\sum_{j=1}^{7} R N_{i j}[j=A A, C, F, P r, S t, V C, V E]
$$

Relative Functional Food Index $R F F I_{i}=\sum_{j=1}^{4} R N_{i j}[j=P h e, P h y, V C, V E]$

\section{Relative Dietary Fiber Index}

$$
\begin{aligned}
& R D F I_{i}=\sum_{j=1}^{5} R N_{i j}[j=A D F, N D F, C e l, H m c, L i g] \\
& R M I_{i}=\sum_{j=1}^{10} R N_{i j}\left[\begin{array}{c}
j=C a, C l, C u, F e, K, M g, M n, N i, P, \\
S, S i, Z n
\end{array}\right]
\end{aligned}
$$

\footnotetext{
where $N i j=$ estimated content of $j$ th nutrient in ith species; $\mathrm{n}=$ total number of plant species; $\mathrm{AA}=$ free amino acids; $\mathrm{C}=$ carbohydrates; $\mathrm{F}=$ fats; $\mathrm{Pr}=$ proteins; $\mathrm{St}=$ starch $; \mathrm{VC}=$ vitamin $\mathrm{C} ; \mathrm{VE}=$ vitamin $\mathrm{E} ; \mathrm{Phe}=\mathrm{Phenols} ; \mathrm{Phy}=\mathrm{Phytosterols} ; \mathrm{ADF}=$ acid detergent fibers; $\mathrm{NDF}=$ neutral detergent fibers; $\mathrm{Cel}=$ cellulose; $\mathrm{Hmc}=$ hemicellulose; $\mathrm{Lig}=$ lignin; $\mathrm{Ca}=$ calcium; $\mathrm{Cl}=$ chlorine; $\mathrm{Cu}=$ copper; $\mathrm{Fe}=$ iron; $\mathrm{K}=$ potassium; $\mathrm{Mg}=$ magnesium; $\mathrm{Mn}=$ manganese; $\mathrm{Ni}=$ nickel; $\mathrm{P}=$ phosphorus; $\mathrm{S}=$ sulphur; $\mathrm{Si}=$ silicon; $\mathrm{Zn}=$ zinc
}

\section{Results And Discussion}

In this study, 90 plant species of 67 genera belonging to 40 families were collected as edible plants from selected sites at Hamirpur district, Himachal Pradesh. Vegetation composition was distributed in various life forms; of which 30 species are as trees (35.3\%, 25 native and five exotic), 11 shrubs (12.9\%, six native and five exotic), 31 herbs (33.0\%, 13 native and 18 exotic) and remaining 18 as creepers $(18.8 \%, 14$ native and four exotic). However, significant numbers of the recorded edible plant species were herbs, followed by trees (the most dominant life form). In contrast, other growth forms of the plant-like shrubs and creepers were sparsely distributed.

Of the total plant species, the maximum was found from family Moraceae (11) followed by Cucurbitaceae (8), Fabaceae (6), Amaranthaceae, Dioscoreaceae, and Rosaceae (5 each); whereas, 14 families like Araceae, Asparagaceae, Asteraceae, Boraginaceae, Chenopodiaceae, Combretaceae, 
Euphorbiaceae, Lythraceae, Myrtaceae, Oxalidaceae, Rhamnaceae, Rutaceae, and Solanaceae were sparsely found ( 2 to 4 species) while remaining 20 families had minimally one species each.

Based on 472 local informants, edible parts of these plants are eaten either in raw or cooked form by the local community. Maximum numbers of wild plants as fruits are generally eaten raw when they are ripe, and usually unripe fruits, seeds, flowers, and leaves are cooked as vegetables by the local people. In the case of individual edible plants, conventional and non-conventional processing is essential to make it palatable. For example, shoots of Bamboo, Agave, and Thoar (Euphorbia royleana) plants need to be peeled, boiled, and fried before consumption, whereas some plants can be directly consumed without processing. Underground parts (tuber) of Dioscorea species require washing, slicing, and boiling in salty water for a particular time and keeping them in salty water overnight to discard the tuber's acrid content. In addition to this, young pods of Cassia fistula are used to prepare pickles and Murabba (a sweet jelly preparation). Young shoots of Euphorbia royleana are being used to prepare vegetables by local people; this is perhaps a new kind of use not reported in the literature.

Local people of the region harness commonly available plants for food and vegetables, such as Aegle marmelos, Bauhinia variegata, Cordia dichotoma, Ficus carica, Ficus palmata, Phyllanthus emblica, Pyrus pashia, Syzygium cumini, Berberis asiatica, Punica granatum, Morus alba, Murraya koenigii, Colocasia esculenta, Amaranthus viridis, Amorphophallus paeoniifolius, Centella asiatica, Chenopodium album, Digera muricata, Ocimum basilicum, Viola serpense, Celastrus paniculatus, Dioscorea species, Monordica dioica etc. In this study, based on a survey, availability of plant, importance, and uses quoted by the informants, 21 plant species were screened for nutrient components and elemental analyses to evaluate their nutritional qualities (Table 2). 
Table 2

Underutilized plant species selected from the study area from Hamirpur district of Himachal Pradesh for nutrient analysis

\begin{tabular}{|c|c|c|c|c|c|c|}
\hline $\begin{array}{l}\text { Voucher } \\
\text { No. }\end{array}$ & $\begin{array}{l}\text { Name of } \\
\text { Plant species }\end{array}$ & $\begin{array}{l}\text { Part } \\
\text { used/ } \\
\text { Analyzed }\end{array}$ & $\begin{array}{l}\text { Area of } \\
\text { collection }\end{array}$ & $\begin{array}{l}\text { Period of } \\
\text { collection }\end{array}$ & $\begin{array}{l}\text { Time of } \\
\text { collection }\end{array}$ & $\begin{array}{l}\text { Informants } \\
\text { (\%) }\end{array}$ \\
\hline 13E001 & $\begin{array}{l}\text { Aegle } \\
\text { marmelos (L.) } \\
\text { Corrêa }\end{array}$ & $\begin{array}{l}\text { Fruit } \\
\text { (Ripe) }\end{array}$ & Badsar, Mehre & $\begin{array}{l}\text { June, July, } \\
\text { August }\end{array}$ & Day & $\leq 95 \%$ \\
\hline $13 \mathrm{E} 046$ & $\begin{array}{l}\text { Amaranthus } \\
\text { viridis } \mathrm{L} \text {. }\end{array}$ & $\begin{array}{l}\text { Leaf/ } \\
\text { young } \\
\text { shoot }\end{array}$ & Hamirpur & $\begin{array}{l}\text { August, } \\
\text { September }\end{array}$ & Morning & $\leq 90 \%$ \\
\hline 13E004 & $\begin{array}{l}\text { Bauhinia } \\
\text { variegata L. }\end{array}$ & $\begin{array}{l}\text { Flower/ } \\
\text { Bud }\end{array}$ & $\begin{array}{l}\text { Samoh } \\
\text { (Badsar), } \\
\text { Salauni } \\
\text { (Hamirpur) }\end{array}$ & $\begin{array}{l}\text { January, } \\
\text { February, } \\
\text { March }\end{array}$ & Morning & $\leq 95 \%$ \\
\hline 13E052 & $\begin{array}{l}\text { Boerhavia } \\
\text { diffusa L. }\end{array}$ & $\begin{array}{l}\text { Leaf/ } \\
\text { Young } \\
\text { shoot }\end{array}$ & $\begin{array}{l}\text { Singhmi } \\
\text { (Barsar) }\end{array}$ & $\begin{array}{l}\text { August, } \\
\text { September }\end{array}$ & Morning & $\leq 70 \%$ \\
\hline- & Ceropegia sp. & Tuber & $\begin{array}{l}\text { Darkotti, Nara, } \\
\text { Samlehara } \\
\text { (Barsar, Bijjari) }\end{array}$ & $\begin{array}{l}\text { February, } \\
\text { March, } \\
\text { April }\end{array}$ & Day & $\leq 70 \%$ \\
\hline 13E054 & $\begin{array}{l}\text { Chenopodium } \\
\text { giganteum } \\
\text { D.Don }\end{array}$ & $\begin{array}{l}\text { Leaf / } \\
\text { Young } \\
\text { shoot }\end{array}$ & $\begin{array}{l}\text { Jhanjiani, } \\
\text { Nain, Nara } \\
\text { (Barsar, Bijari) }\end{array}$ & $\begin{array}{l}\text { May, June, } \\
\text { July, } \\
\text { August }\end{array}$ & Morning & $\leq 80 \%$ \\
\hline 13E0072 & $\begin{array}{l}\text { Coccinia } \\
\text { grandis (L.) } \\
\text { Voigt }\end{array}$ & $\begin{array}{l}\text { Fruit } \\
\text { (Unripe) }\end{array}$ & $\begin{array}{l}\text { Tikru, Charot, } \\
\text { Bhadola } \\
\text { (SujanpurTira) }\end{array}$ & $\begin{array}{l}\text { August, } \\
\text { September }\end{array}$ & Day & $\leq 85 \%$ \\
\hline 13E043 & $\begin{array}{l}\text { Colocasia } \\
\text { esculenta (L.) } \\
\text { Schott }\end{array}$ & $\begin{array}{l}\text { Leaf/ } \\
\text { Tuber }\end{array}$ & $\begin{array}{l}\text { DharBagerah, } \\
\text { Bahru } \\
\text { (SujanpurTira) }\end{array}$ & $\begin{array}{l}\text { July, } \\
\text { August, } \\
\text { September } \\
\text { (Available } \\
\text { in } 12 \\
\text { months) }\end{array}$ & Morning & $\leq 90 \%$ \\
\hline 13E008 & $\begin{array}{l}\text { Cordia } \\
\text { dichotoma } \\
\text { G.Forst. }\end{array}$ & $\begin{array}{l}\text { Fruit } \\
\text { (unripe) }\end{array}$ & $\begin{array}{l}\text { JolKalan, } \\
\text { Tikkar } \\
\text { (SujanpurTira) }\end{array}$ & $\begin{array}{l}\text { June, July, } \\
\text { August }\end{array}$ & Day & $\leq 95 \%$ \\
\hline 13E057 & $\begin{array}{l}\text { Digera } \\
\text { muricata (L.) } \\
\text { Mart. }\end{array}$ & $\begin{array}{l}\text { Leaf/ } \\
\text { Young } \\
\text { shoot }\end{array}$ & $\begin{array}{l}\text { Barsar, Sarai } \\
\text { (Barsar, } \\
\text { Nadaun) }\end{array}$ & $\begin{array}{l}\text { August, } \\
\text { September }\end{array}$ & Morning & $\leq 80 \%$ \\
\hline $13 \mathrm{E} 076$ & $\begin{array}{l}\text { Dioscorea } \\
\text { alata L. }\end{array}$ & $\begin{array}{l}\text { Airbulbils/ } \\
\text { Tuber }\end{array}$ & $\begin{array}{l}\text { DharBagerah, } \\
\text { Kodana } \\
\text { (SujanpurTira), } \\
\text { Barsar }\end{array}$ & $\begin{array}{l}\text { November, } \\
\text { December }\end{array}$ & Day & $\leq 75 \%$ \\
\hline
\end{tabular}

a available on the high altitude range 


\begin{tabular}{|c|c|c|c|c|c|c|}
\hline $\begin{array}{l}\text { Voucher } \\
\text { No. }\end{array}$ & $\begin{array}{l}\text { Name of } \\
\text { Plant species }\end{array}$ & $\begin{array}{l}\text { Part } \\
\text { used/ } \\
\text { Analyzed }\end{array}$ & $\begin{array}{l}\text { Area of } \\
\text { collection }\end{array}$ & $\begin{array}{l}\text { Period of } \\
\text { collection }\end{array}$ & $\begin{array}{l}\text { Time of } \\
\text { collection }\end{array}$ & $\begin{array}{l}\text { Informants } \\
(\%)\end{array}$ \\
\hline- & $\begin{array}{l}\text { Dioscorea } \\
\text { belophylla } \\
\text { (Prain) Voigt } \\
\text { ex Haines }\end{array}$ & Tuber & $\begin{array}{l}\text { Dhaneta, } \\
\text { Amroa } \\
\text { (Nadaun), } \\
\text { PathliarUparla } \\
\text { (Barsar) }\end{array}$ & $\begin{array}{l}\text { December, } \\
\text { January }\end{array}$ & Afternoon & $\leq 85 \%$ \\
\hline 13E074 & $\begin{array}{l}\text { Dioscorea } \\
\text { bulbifera L. }\end{array}$ & Tuber & $\begin{array}{l}\text { Mehalkhass, } \\
\text { Tikker }\end{array}$ & $\begin{array}{l}\text { December, } \\
\text { January }\end{array}$ & Afternoon & $\leq 50 \%$ \\
\hline \multirow[t]{2}{*}{ 13E075 } & $\begin{array}{l}\text { Dioscorea } \\
\text { deltoidea }\end{array}$ & Tuber & $\begin{array}{l}\text { At Border area } \\
\text { of Sujanpur } \\
\text { Tira and }\end{array}$ & $\begin{array}{l}\text { October, } \\
\text { November }\end{array}$ & Afternoon & $\leq 65 \%$ \\
\hline & $\begin{array}{l}\text { Wall. ex } \\
\text { Griseb. }\end{array}$ & & Kangra $^{a}$ & & & \\
\hline- & $\begin{array}{l}\text { Dioscorea } \\
\text { pentaphylla L. }\end{array}$ & Tuber & $\begin{array}{l}\text { Nara, Upper } \\
\text { Pathliar }\end{array}$ & $\begin{array}{l}\text { January, } \\
\text { February }\end{array}$ & Afternoon & $\leq 88 \%$ \\
\hline $13 \mathrm{E} 010$ & $\begin{array}{l}\text { Diospyros } \\
\text { melanoxylon } \\
\text { Roxb. }\end{array}$ & $\begin{array}{l}\text { Fruit } \\
\text { (Ripe) }\end{array}$ & $\begin{array}{l}\text { The border } \\
\text { area of Una } \\
\text { and Hamirpur } \\
\text { district }\end{array}$ & June, July & Day & $\leq 50 \%$ \\
\hline 13E079 & $\begin{array}{l}\text { Momordica } \\
\text { dioica Roxb. } \\
\text { ex Willd. }\end{array}$ & $\begin{array}{l}\text { Fruit } \\
\text { (Unripe) }\end{array}$ & $\begin{array}{l}\text { Darkoti, Baroh } \\
\text { (Bamson) }\end{array}$ & $\begin{array}{l}\text { July, } \\
\text { August }\end{array}$ & Day & $\leq 90 \%$ \\
\hline- & $\begin{array}{l}\text { Moringa } \\
\text { oleifera Lam. }\end{array}$ & Fruit & & & & \\
\hline 13E024 & $\begin{array}{l}\text { Pyrus pashia } \\
\text { Buch.-Ham. } \\
\text { ex D.Don }\end{array}$ & $\begin{array}{l}\text { Fruit } \\
\text { (Ripe, } \\
\text { Unripe) }\end{array}$ & $\begin{array}{l}\text { Amroa, Karari } \\
\text { (Nadaun), } \\
\text { Darkoti } \\
\text { (Barsar) }\end{array}$ & November & Day & $\leq 85 \%$ \\
\hline $13 \mathrm{E} 025$ & $\begin{array}{l}\text { Spondias } \\
\text { pinnata (L.f.) } \\
\text { Kurz }\end{array}$ & $\begin{array}{l}\text { Fruit } \\
\text { (Unripe) }\end{array}$ & $\begin{array}{l}\text { Baloh, Raj } \\
\text { nauni } \\
\text { (Nadaun) }\end{array}$ & $\begin{array}{l}\text { January, } \\
\text { February }\end{array}$ & Day & $\leq 70 \%$ \\
\hline 13E084 & $\begin{array}{l}\text { Trichosanthes } \\
\text { cucumerina L. }\end{array}$ & $\begin{array}{l}\text { Fruit } \\
\text { (Unripe) }\end{array}$ & Hamirpur & $\begin{array}{l}\text { August, } \\
\text { September }\end{array}$ & Day & $\leq 83 \%$ \\
\hline
\end{tabular}

\section{Evaluation of edible plants on nutritive values}

A balanced and adequate diet constitutes two components, viz. food (nutrition) and functional food. Nutritional food mainly includes proteins, carbohydrates, lipids (fat). The nutritional value is the primary concern when a crop is being considered as a food source. Due to the emphasis placed on consumers' nutritional value, a great need exists for information on crops' nutritional contents [35]. However, an ideal 
edible plant species should be having the following qualities: a) rich content of proteins, carbohydrates, fats, dietary fiber, and minerals, b) balanced amount of nutraceutical substances, particularly vitamins $C$, $\mathrm{E}$, and $\mathrm{B}_{12}$, C) Substantial amount of essential macro elements such as $\mathrm{Na}, \mathrm{K}, \mathrm{Ca}$ and $\mathrm{Mg}$ and microelements such as $\mathrm{Fe}, \mathrm{Cu}, \mathrm{Zn}, \mathrm{Mn}, \mathrm{Ag}$ and $\mathrm{Au}, \mathrm{d}$ ) medicinal importance e) economic importance and commonly available to the local people. Based on specific criteria like survey, availability, use, and application by the local people for food and medicine; therefore, we screened 21 plant species out of ninety for nutrient component analysis.

\section{Carbohydrate}

Similarly, the allocation of carbohydrates was calculated and presented in Fig. 1. Since carbohydrates are primary energy generating (yielding) substances, they are regarded as the chief energy source to each organism. They are mainly composed of starch and sugars. Among species, Dioscorea bulbifera showed the richest allocation of carbohydrate (80.57\%), followed by A. marmelos (73.8\%), D. alata (73.19) Ceropegia sp. (72.36\%), and D. melanoxylon (72.2\%). Remaining some other species (D. pentaphylla, $T$. cucumerina, B. variegata, P. pashia, and S. pinnata) also exhibited a comparable allocation range of carbohydrates. It has been noted that $D$. muricata has the highest allocation for protein but least for carbohydrates. However, a variable range of carbohydrates as total nutrients found in the selected species, where $50 \%$ species allocated $50 \%$ of carbohydrates and $25 \%$ species showed $30 \%$ allocation (Fig. 1).

Based upon this finding, few species such as D. bulbifera, Ceropegia sp., D. pentaphylla, D. alata, Bauhinia variegata, $A$. marmelos, and $D$. melanoxylon can be recommended as a good source of carbohydrates. The starch allocation was higher in all Dioscorea species except $S$. pinnata with the maximum allocation (37.0\%). In agreement with our study, some earlier studies, for example, Baliga et al. (2011) reported $31.8 \%$ carbohydrate in the fruit of Aegle marmelos [42] and Zehra et al. (2015) reported 34.35\% carbohydrates in the same plant species (Aegle marmelos) from Pakistan and another recent study [43], Binish and Pushpa (2018) revealed 34.43 to $46.16 \mathrm{~g} / 100 \mathrm{~g}$ highest nutrient value of carbohydrates in tubers of three Ceropegia sp. [44].

\section{Fat content}

Fat is also the primary source of metabolic energy, which indirectly regulates the flow of materials into and out of the cell. Dietary fat serves as a carrier of vitamins, A, D, E, K, and hormones. In our study, allocation of fat of the total nutrients provides impressive results among all selected species. For example, Colocasia esculenta is rich in carbohydrates but provided the highest fat allocation, followed by Boerhavia diffusa and T. cucumerina. The least amount was recorded in the fruit of $D$. melanoxylon (Fig. 2). Generally, plant components, leaves, and seeds provide a rich source of fat. In our study, fat content was analyzed from leaf, and a high content was recorded, for example, $C$. esculenta, $B$. diffusa, $C$. giganteum, and $A$. viridis. Furthermore, few species were observed to have a high concentration of fat (lipid) content in the present study that can be an excellent fat source. 
Generally, food plant species possess fat content ranging from $0.1-5 \%$ or even above. Earlier studies observed that edible plant species' fat content varies with species, parts, and area of study. For example, the fat content in Boerhavia diffusa was found to be $1.16 \%$ [45], whereas it was $0.7 \%$ in leaves of Amaranthus sp. [46]. Similarly, the fat content was reported about $1.8 \%$ [47] and 5.5-7.4\% in the same species Chenopodium quinoa [48], but from different study areas. These studies altogether support the present study's findings as the fat content of all leafy vegetables was approximately within the range recorded by earlier studies.

\section{Protein}

Dietary protein is the most critical constituent among all other nutrient components, primarily involved in the growth, maintenance, and repair of the body tissue. It regulates all the processes within the body [36]. Excess protein is used as a source of energy. Based on the allocation of total protein among selected plant species, Digera muricata is found most important edible species and is allocated with a high percentage of protein (46.52\%) as of total nutrients (Carbohydrate + fat + protein) followed by $A$. viridis (22.73\%), C. giganteum (19.82\%) and Bauhinia variegata (17.97\%), whereas, least allocation was found in Ceropegia species (1.46\%). Sharma et al. (2011) and Usmani et al. (2014) reported protein content $78.0 \mathrm{mg} / \mathrm{g}$ and $4.3(\mathrm{~g} / 100 \mathrm{~g})$ in Digera muricata respectively on a dry basis, which is lower than the present estimation of the same species [37,38]. Out of all selected plant species, seven (07) species showed more than $10 \%$ while four species had less than $5 \%$ protein allocation. It was further observed that more than $15 \%$ allocation of protein was recorded in all leafy vegetable plants except $C$. esculenta. Specifically, one fruit plant (C. grandis) exhibited more than $15 \%$ protein allocation. Hence, those plants with a high protein percentage are presumably the most important edible species as a protein source that can be recommended to people deficient in protein nutrients. Therefore, the variation in the protein contents depends upon the season of collection, location and genetic variations of the species, etc. However, leafy vegetables' variation ranged from 0.33 to $21.79 \mathrm{~g} / 100 \mathrm{~g}$ [39-40]. The lowest value $(0.57 \mathrm{~g} / 100 \mathrm{~g})$ was found in the fruits of Trichosanthes cucumerina. The result of the same was confirmed and reported precisely by Badejo et al. (2016), who reported protein 0.37 to 0.51 (g/100 g on a fresh weight basis) in the same species [41]. The amino acid allocation was recorded maximum in the species like A. viridis (27.9\%) followed by B. diffusa, C. grandis, M. dioica, C. dichotoma, and C. giganteum (Fig. 3).

\section{Vitamin-C}

Allocation of vitamin-C of total nutrients in the selected species reflected a contrasting range from 0.01 $1.0 \%$. S. pinnata had the highest allocation, followed by M. dioica, B. diffusa, $A$. viridis, and $B$. variegata (Fig. 4). However, 6-7 species showed an intermediate-range, but those species that showed a higher range of allocation for protein and carbohydrate had low allocation for Vitamin-C. Surprisingly, one species $D$. muricata with the highest allocation for protein, a substantial amount of carbohydrates, exhibited an acceptable range of vitamin-C allocation slightly lower than $A$. viridis (a leaf vegetable). Vitamin- $\mathrm{C}$ generally is a good source for immunity enhancement, protection from various diseases. 
Various workers $[49,50]$ have reported vitamin C content in Spondias pinnata in the range of 21$218 \mathrm{mg} / 100 \mathrm{~g}$. In another study, Nirmala et al. (2007) reported contents of vitamin- C (3.0-13 mg/100 g) fresh weight basis) in the shoots of bamboo species [51]. In comparison, another study conducted by Badejo et al. (2016) reported 39.32-56.58 Vitamin C content in the fruits of Trichosanthes cucumerina on a dry weight basis [41], which is in line with our findings.

\section{Vitamin-E}

B. diffusa had the highest allocation of vitamin-E followed by $C$. giganteum and S. pinnata whereas it was lowest in Ceropegia sp. and $C$. dichotoma (Fig. 5). The remaining 18 species were found in the range of $0.001-0.009 \%$. Important vitamin-rich plant species mentioned above can be recommended as healthy diets, especially for nutrient-deficient areas. Vitamin-E is required for skincare, hair growth and also regarded as a beauty vitamin. It is a powerful antioxidant that protects the heart, blood vessels, chest pain, high blood pressure, blocked arteries, anti-aging, cancer, liver toxicity, etc. [52]. The range of vitaminE content was varied from 0.05 to $16.4 \mathrm{mg} / 100 \mathrm{~g}$ in different species mentioned above by different workers [53-54]. Hence, these plants such as Aegle marmelos, Pyrus pashia, Spondias pinnata, Boerhavia diffusa, Chenopodium giganteum, etc. can be considered the sources for vitamin E supplement for local people, if it is commercialized, rest of other people would be benefitted more.

\section{Relative nutrient value index (RNVI)}

RNVI was calculated as a summation of the proportional value of major components such as protein, carbohydrate, and fat of each species. This provided adequate information for the evaluation of a plant species. Values for RNVI varied from 7-36, in which the highest was estimated for $C$. esculenta (34.76) followed by $A$. marmelos (31.32) and $D$. deltoidea (30.91). Local people of the study site also informed about its efficacy for edible and medicinal purposes. Across species, ten species had RNVI value in the range of (20-30), and three species had above 30 index values (Fig. 6). Taro corm (C. esculenta) is a good source of minerals. Its starch's small granule size helps increase its nutrients' bioavailability due to the efficiency of digestion and absorption [55].

\section{Relative functional food index (RFFI)}

TRFFI was calculated in the same way that it also provides sufficient information about rich food value content such as vitamin-C, E, total phenol, and phytosterol. Based on the analyzed concentration of phytosterol and phenol, it is not easy to figure out the species' quality. However, through this index, it is found that S. pinnata (34.81) had a higher or better index for functional food value, followed by Dioscorea alata (26.11), Bauhinia variegata (26.01), C. giganteum (25.44), Dioscorea pentapyhlla, (24.44) and Moringa oleifera (21.18). The remaining four species exhibited TRFFI value around 20 (Fig. 7). Since functional food is the composition of phytosterol, total phenol, and vitamins, they are required for protection from harmful diseases [56-57]. 
Generally, phytonutrients are present in the foodstuff. They may be used as food supplements and as medicinal food. Based on a single constituent like total phenol or phytosterol, it might be challenging to evaluate the quality of species for functional food value. Hence, this index provides satisfactory results. Based on this index, S. pinnata, D. alata, D. pentaphylla, C. giganteum can be recommended as a good source for functional food development. They are known to have several bioactive properties with possible implications for human health, such as the serum cholesterol-lowering effect, that might prevent colon cancer and benign prostatic hyperplasia [58]. Recommended daily dietary intake of naturally occurring phytosterols is ranged from 150-450 mg/day. Intake of Phytosterol is negatively correlated with cholesterol absorption.

\section{Relative Dietary fiber index (RDFI)}

RDFI is calculated in a similar way to another index like TRMI and TRFFI. Values for respective index varied from 9.05-35.61, in which C. esculenta (35.61) and C. giganteum (35.53) both had the highest while Ceropegia species exhibited the lowest value of RDFI (Fig. 8). Across species, 12 species showed 12-25 IRDF values while eight species had in the range of 10-12. This index can act as a better tool to distinguish species having a rich source of fiber content. Therefore, through this index, we found these two species to have surprisingly better fiber content, followed by C. dichotoma (32.06), P. pashia (29.48) A. viridis (29.38), leaf of C. esculenta (25.92), and Digera muricata (25.36) respectively. Nirmala et al. (2011) and Bajwa et al. (2016) reported 0.51-1.93 g/100 g (fresh weight) in the shoot of Bamboo species [18,59]. Modgil and Sood (2015) and Vilcacundo et al. (2018) recorded dietary fiber of leafy plant species within range with our findings $[60,48]$. Plant food contains non-digestive carbohydrates like ADF, NDF, cellulose, hemicellulose, and lignin. These indigestible carbohydrates are designated as dietary fiber. Intake of dietary fiber has essential metabolic and physiological effects. Though they do not constitute the nutritive value of foods. The presence of fiber is commonly called roughage of diet, which is necessary for digestion and elimination of waste. It helps to solve constipation, blood glucose, reduce the risk of colon cancer, etc. Hence, these plants can be used as better sources of dietary fiber. In 2015, the government published new guidelines to recommend that fiber intake should increase to $30 \mathrm{~g}$ a day for adults for more than 17 years.

\section{Relative mineral index (RMI)}

About 12 main elements ( $\mathrm{Ca}, \mathrm{Cu}, \mathrm{Fe}, \mathrm{K}, \mathrm{Mg}, \mathrm{Mn}, \mathrm{Ni}, \mathrm{P}, \mathrm{Zn}, \mathrm{Na}, \mathrm{Si}, \mathrm{S}$ ) are considered to calculate this index. Values for the corresponding index (TRMI) varied from 13-174.03 in which D. muricata exhibited the highest value, followed by $A$. viridis (101.39), C. esculenta (98.45), C. giganteum (85.04), B. diffusa (73.25), and Ceropegia (67.1). The remaining other species (12) had a more or less similar range of (IRMN) while 8 species had a range below 30 (Fig. 9). This index probably provides valuable information and evaluates mineral enrichment of the species. D. muricata with highest protein allocation and highest mineral nutrients indicates that this plant can be recommended as a good source for protein and minerals rich species. In India, malnutrition is a common problem in women, older people, and children below 12 , mainly residing in remote rural areas. However, if present in the plant, these elements may be a 
good substitute for food and a source for those specific elements required for curing ailments of a human and veterinary purpose. Some minerals are essential to the human body, e.g., such as calcium, potassium, magnesium, sodium, phosphorus, and chloride. These are required in a large amount while others in a small quantity, usually less than $0.01 \%$ of the total body weight [57].

Most rural people suffer from malnutrition not because of the economic status but because of the inability to utilize the available nutritious underutilized crops to meet their daily requirements. There must be a need to see the economic and nutritional impact of indigenous fresh underutilized crops for its production and consumption in rural communities to meet the nutritional demand. Therefore, it can be useful for malnutrition and food insecurity for rural peoples as rural food sources. The metabolic fate or role of each element in the plant can be characterized in relation to some basic processes such as uptake (absorption), transport within plants, concentration, metabolic process, and deficiency and toxicity.

Generally, plants absorb elements through roots from the soil and aerial parts like a leaf, also known as foliar uptake, which occurs in two-phase non-metabolic cuticle parts and metabolic transportation across the cell membrane. Some elements such as $\mathrm{Cu}, \mathrm{Fe}, \mathrm{Mn}, \mathrm{Mg}$, and $\mathrm{Zn}$ play a crucial role in plant metabolism and are constituents of several enzymes.

The trace elements play an important key role in human metabolism. Low food quality has created severe problems for the people; this situation is alarming, especially in developing nations where most people do not have sufficient food even in one-time food intake. However, more surprising facts are that those people who are getting enough food (three times daily) are undernourished. Nowadays, over three billion people worldwide suffer from either deficiency or where presence in excess may result in toxicity of some elements. Some trace elements are essential for chemical, biological, biochemical, metabolic, catabolic, and enzymatic activities in plants, animals, and human beings. Trace elements can remain in the body organs for a long time. It has been reported that more than 60 elements have been detected from the human body in which about 25 elements are essential for human health, where 14 are trace metals that can prevent malnutrition.

\section{Conclusions}

In this study, it is found that all selected plants are significant in one or other way considering each parameter as recommended by the indigenous people of the study site. A scientific study of the plants corroborated with the information provided by the locals during the survey. Some plants are found to have a higher content of protein (Digera muricata, Amaranthus viridis, Chenopodium sp.), Carbohydrates (tuber of Dioscorea sp. Ceropegia species, Aegle marmelos), vitamin C (Spondias pinnata fruit, Momordica dioica, Aegle marmelos, and leafy plants Amaranthus species), vitamin E (Colocasia esculenta tuber, Aegle marmelos, Pyrus pashia, Spondias pinnata), Iron (Digera muricata, Amaranthus sp, Colocasia esculenta), Calcium (Digera muricata, Colocasia esculenta, Amaranthus sp., Boerhavia diffusa), Potassium (Digera muricata; Amaranthus sp., Colocasia esculenta), Magnesium (Digera muricata, Amaranthus sp., Ceropegia sp.). While highest RNVI was found in $C$. esculenta (tuber), TRFFI in S. pinnata, RDFI in C. esculenta (leaf) and C. giganteum and highest TRMI was in D. Muricata, thus, these 
species can be explored as essential food plants and be promoted in rural as well as urban regions for cultivation and commercialization.

Higher mineral content and nutritive components (proteins and vitamins) of these plants may provide an array to utilize the plants to form dietary supplements on a commercial scale. In addition to their nutritional importance, selected underutilized plants also have high medicinal importance that can be further investigated to commercialize their use for medicinal purposes (which can be a good option for searching for new medicines). Although the present study documented the various underutilized plants (of Hamirpur district, H.P.), their use values as food along with their medicinal importance, further research is required to efficiently conserve and commercialize these underutilized plants in order to save the traditional knowledge of ethnobotany and to utilize them for their dietary and medicinal importance to fulfill the ever-increasing requirements of the human population.

\section{Declarations}

\section{Ethics approval and consent to participate}

Not applicable.

\section{Consent for publication}

Not applicable.

\section{Availability of data and materials}

All data generated or analyzed during this study are included in this published article.

\section{Competing interests}

The authors declare that they have no competing interests.

\section{Funding}

RCB is grateful to the University Grants Commission (UGC), Government of India, New Delhi for financial support in the form of a Teacher Fellowship Award. AK, PK, and ShS are also thankful to the University Grants Commission (UGC), Government of India, New Delhi for the financial support in the form of a Junior Research Fellowship (JRF).

\section{Authors' contributions}


Conception and design: ANS and CN; Field data collection: RCB, RP, VK, and SiS; Identification and biochemical analysis: RCB, RP, and VK; Data analysis and interpretation: RCB, RP, AK, and ANS; Initial draft: RCB, RP, PK, and AK; Revision: AK, PK, ShS and ANS; Supervision: ANS and CN. All authors read and approved the final manuscript.

\section{Acknowledgments}

We are very thankful to the local people and administration of Hamirpur district of Himachal Pradesh for providing necessary facilities and kind cooperation during the fieldwork. Thanks are due to the Chairperson, Department of Botany, Panjab University, and Chandigarh to provide the required facilities during work. Also, RCB is grateful to the Department of Higher Education, Haryana, and Principal, Smt. Aruna Asaf Ali Government Postgraduate College, Kalka for granting study leave for doctoral research work.

\section{Authors' information}

${ }^{1}$ Smt. Aruna Asaf Ali Govt. Post Graduate College, Kalka (Panchkula), Haryana, INDIA

${ }^{2}$ Soil Ecosystem and Restoration Ecology Lab, Department of Botany, Panjab University, Chandigarh 160014, INDIA

${ }^{3}$ Department of Environment Studies, Panjab University, Chandigarh 160014, INDIA

${ }^{4}$ Department of Botany, Panjab University, Chandigarh 160014, INDIA

\section{References}

1. Sinha K, Khare V. Nutritional and medicinal value of underutilized vegetable crops in India. Int J Chem Stud. 2018;6(1):2067-2072.

2. Bhatti RC, Nirmala C, Kaur A, Singh S, Kumar P, Kaur R, Singh AN. Harnessing of local plant species by indigenous people of Hamirpur district for ethno-veterinary purposes. Ann Plant 2017;6(12):18981925.

3. Food and Agriculture Organization. Integrating Agriculture into National Adaptation Plans (NAP-Ag), Rome. 2018. Available from: www.fao.org/ in-action/naps.

4. Chand R, Kaur R, Kaur A, Kumar V, Nirmala C, Singh AN. Assessment of ethnomedicinal plant diversity of Una and Hamirpur district of Himachal Pradesh, India: an ethno-ecological approach. Ann PlantSci. 2016; 5:1475-1490.

5. Chand R, Singh AN, Nirmala C. Ethnoecological survey of underutilized plant diversity of Hamirpur district, Himachal Pradesh, India: an edibility assessment. Environ Ecol Res.2017;5(1), 13-29. 
6. Harjit K, Amini MH, Suttee A. Evaluation of antioxidant and anthelmintic properties of Caesalpinia sappan leaves. Int J Pharmacogn Phytochem Res. 2016; 8:362-8.

7. Topwal M. Review on Amaranth: Nutraceutical and Virtual Plant for Providing Food Security and Nutrients. Acta scientific agriculture. 2019;3(1):9-15.

8. Mahapatra AK, Panda PC. Wild edible fruit diversity and its significance in the livelihood of indigenous tribals: evidence from eastern India. Food 2012;4(2):219-34.

9. Santosh O, Bajwa HK, Bisht MS, Nirmala C. Functional biscuits from bamboo shoots: Enrichment of nutrients, bioactive compounds and minerals in bamboo shoot paste fortified biscuits. Int J FoodSci Nutr. 2019;4(1):89-94.

10. Maikhuri RK, Nautiyal S, Rao KS, Semwal RL. Indigenous knowledge of medicinal plants and wild edibles among three tribal sub communities of the central Himalayas, India. Indigenous Knowledge and Development Monitor, 2000;8(2): 7-13.

11. Nazarudeen A. Nutritional composition of some lesser-known fruits used by ethnic communities and local folks of Kerela. Ind. J. Traditional Knowl. 2010;9(2):398-402.

12. Aberoumand A, Deokule SS. Studies on nutritional values of some wild edible plants from Iran and India. Pak JNutr. 2009;8(1): 26-31.

13. Musinguzi EL, Kikafunda JK, Kiremire BT. Promoting indigenous wild edible fruits to complement roots and tuber crops in alleviating vitamin A deficiencies in Uganda. In Proceedings of the 13th ISTRC Symposium. 2007;(pp. 763-769).

14. Nkafamiya II, Modibbo UU, Manji AJ, Haggai D. Nutrient content of seeds of some wild plants. Afr J Biotechnol. 2007;6(14).

15. Glew RS, VanderJagt DJ, Bosse R, Huang YS, Chuang LT, Glew RH. The nutrient content of three edible plants of the Republic of Niger. JFood Compos Anal. 2005;18(1):15-27.

16. Reddy KN, Pttanaik C, Reddy CS, Raju VS. Traditional knowledge on wild food plants in Andhra Pradesh. Indian J Tradit Knowl. 2007;6(1):223-229.

17. Pal RS, Kumar RA, Kant L, Bhatt JC. Kilmora: A Wild Edible Potential Nutraceutical Fruit in Indian Himalayan Region. Popular Kheti. 2014;2(3):199-203.

18. Nirmala C, Bisht MS, Haorongbam S. Nutritional properties of bamboo shoots: potential and prospects for utilization as a health food. ComprRev Food Sci Food Saf. 2011:10(3):153-168.

19. Nirmala C, Bisht MS, Laishram M. Bioactive compounds in bamboo shoots: health benefits and prospects for developing functional foods. Int J Food Sci Technol.2014;49(6):1425-1431.

20. Nirmala C, Bisht MS. 10 WBC Reports: Bamboo: A prospective ingredient for functional food and nutraceuticals. Bamboo journal. 2017;30:82-99.

21. Nirmala C, Bisht MS, Bajwa HK, Santosh O. Bamboo: A rich source of natural antioxidants and its applications in the food and pharmaceutical industry. Trends FoodSci Technol. 2018;77:91-99.

22. Bajwa HK, Santosh O, Koul A, Bisht MS, Nirmala C. Quantitative determination of macroelement and microelement content of fresh and processed bamboo shoots by wavelength dispersive X-ray 
fluorescence spectrometry. X-ray Spectrom. 2019;48(6):637-43.

23. Grusak MA, DellaPenna D. Improving the nutrient composition of plants to enhance human nutrition and health. Annu Rev Plant 1999;50(1):133-61.

24. Lee YP, Takahashi T. An improved colorimetric determination of amino acids with the use of ninhydrin. Anal Biochem. 1966;14(1):71-77.

25. Bradford MM. A rapid and sensitive method for the quantitation of microgram quantities of protein utilizing the principle of protein-dye binding. Anal Biochem. 1976;72(1-2):248-54.

26. Whistler RL. Methods in carbohydrate chemistry. Academic press inc. New York, 1971;1-6.

27. McCready RM, Guggolz J, Silviera V, Owens HS. Determination of starch and amylose in vegetables. Anal Chem. 1950;22(9):1156-8.

28. Official methods of analysis of the AOAC, 15th ed. Methods 932.06, 925.09, 985.29, 923.03. Association of official analytical chemists. Arlington, VA, USA. 1990.

29. Goering HK, Van Soest PJ. Forage fiber analyses (apparatus, reagents procedures and some applications). Agriculture handbook No. 379 USDA, Washington, Dc. 1970;pp.1-20,.

30. Riemschneider R, Abedin MZ, Mocellin RP. Qualities and stabilisierungprufung hitzekonservierter Nahrungsmittel unter verwendung von Vit C als kri kriterium-Mittel. Alimenta. 1976;15:171.

31. Baker T, Lowndes HE, Johnson MK, Sandborg IC. The effects of phenylmethanesulfonyl fluoride on delayed organophosphorus neuropathy. Arch Toxicol. 1980;46(3-4):305-11.

32. Harbers LH. Ash analysis In: Introduction to Chemical Analysis of Foods. Jones and Bertlett Publishers, Boston, London. 1994:113-21.

33. Singleton VL, Rossi JA. Colorimetry of total phenolics with phosphomolybdic-phosphotungstic acid reagents. Am J Enol Vitic. 1965;16(3):144-158.

34. Srivastava RC. Bamboo, new raw material for phytosterols. Curr Sci. 1990;59(24):1333-1334.

35. Huang KH, Li X, Ravindran V, Bryden WL. Comparison of apparent ileal amino acid digestibility of feed ingredients measured with broilers, layers, and roosters. Poult Sci. 2006;85(4):625-34.

36. Tou EH, Mouquet-Rivier C, Picq C, Traoré AS, Trèche S, Guyot JP. Improving the nutritional quality of ben-saalga, a traditional fermented millet-based gruel, by co-fermenting millet with groundnut and modifying the processing method. LWT-Food Sci Technol. 2007;40(9):1561-1569.

37. Sharma N, Tanwer BS, Vijayvergia R. Study of primary metabolites and antimicrobial activities of Digera muricata (L.) Mart. J Chem Pharm Res. 2011;3(2):424-431.

38. Usmani S, Hussain A, Farooqui AH, Arshad M, Siddiqui S, Ahmad M, Wahab S. Anti-proliferative Activity of Crude Extract and Fractions Obtained from Digera muricata on HeLa Cell Lines of Human Cervix and A 549 Cell Lines of Human Lung. Pharmacogn Mag. 2014;6(6).

39. Youkai X, Hongmao L, Xiangsheng D, Chunfen X, Chuantao C, Guanghong C, Ziyan X. Nutrients content of Bauhinia variegata candida and its value as an edible wild flower. J Yunnan Univ Nat Sci Ed. 2004;26(1):88-92. 
40. Verma RK. An ethnobotanical study of plants used for the treatment of livestock diseases in Tikamgarh District of Bundelkhand, Central India. Asian Pac J Trop 2014;4:S460-S467.

41. Badejo AA, Adebowale AP, Enujiugha VN. Changes in nutrient composition, antioxidant properties, and enzymes activities of snake tomato (Trichosanthes cucumerina) during ripening. Prev Nutr Food 2016;21(2):90.

42. Baliga MS, Bhat HP, Joseph N, Fazal F. Phytochemistry and medicinal uses of the bael fruit (Aegle marmelos Correa): A concise review. Food Res Int. 2011;44(7):1768-1775.

43. Zehra A, Dubey MK, Tiwari A, Meena M, Kumari P, Singh VK, Gupta VK, Upadhyay RS. Fungal biomolecules and their implications, In Fungal Biomolecules: Sources, Applications and Recent Developments, eds. Gupta VK, Mach RL, Sreenivasaprasad S. Chichester: John Wiley and Sons, Ltd. 2015;19:365.

44. Binish T, Pushpa R. Pharmaceutical and nutraceutics on three endemic species of Ceropegia Ann PlantSci. 2018;7(5):2221-2225.

45. Puranik V, Chauhan DK, Mishra V, Rai GK. Effect of drying techniques on the physicochemical and bioactive components of selected medicinal herbs. Ann Phytomed. 2012;1:23-9.

46. Misra S, Maikhuri RK, Kala CP, Rao KS, Saxena KG. Wild leafy vegetables: A study of their subsistence dietetic support to the inhabitants of Nanda Devi Biosphere Reserve, J Ethnobiol Ethnomed. 2008;4(1):15.

47. Nowak V, Du J, Charrondière UR. Assessment of the nutritional composition of quinoa (Chenopodium quinoa). Food Chem. 2016;193:47-54.

48. Vilcacundo R, Miralles B, Carrillo W, Hernández-Ledesma B. In vitro chemopreventive properties of peptides released from quinoa (Chenopodium quinoa) protein under simulated gastrointestinal digestion. Food Res Int. 2018;105:403-11.

49. Kozioł MJ, Macía MJ. Chemical composition, nutritional evaluation, and economic prospects of Spondias purpurea (Anacardiaceae). Econ Bot. 1998;52(4):373-380.

50. Gosh A, Das S, Mallipeddi R, Das AK, Dash SS. A modified differential evolution with distance-based selection for continuous optimization in presence of noise. IEEE Access. 2017;5:26944-26964.

51. Nirmala C, David E, Sharma ML. Changes in nutrient components during ageing of emerging juvenile bamboo shoots. Int JFood Sci Nutr. 2007;58(8):612-618.

52. Aziz M, Karboune S. Natural antimicrobial/antioxidant agents in meat and poultry products as well as fruits and vegetables: A review. Crit Rev FoodSci Nutr. 2018;58(3):486-511.

53. Halík T. Patience with God: The story of Zacchaeus continuing in us. Doubleday Religion. 2009.

54. Singh BN, Singh BR, Singh RL, Prakash D, Singh DP, Sarma BK, Upadhyay G, Singh HB. Polyphenolics from various extracts/fractions of red onion (Allium cepa) peel with potent antioxidant and antimutagenic activities. Food Chem. Toxicol. 2009;47(6):1161-1167.

55. Temesgen M, Retta N. Nutritional potential, health and food security benefits of taro Colocasia esculenta (L.): A review. Food Science and Quality Management. 2015; 36:23-30. 
56. Blando F, Gerardi C, Nicoletti I. Sour cherry (Prunus cerasus L) anthocyanins as ingredients for functional foods. JBiomed Biotechnol. 2004;2004(5):253.

57. El Abbassi A, Khalid N, Zbakh H, Ahmad A. Physicochemical characteristics, nutritional properties, and health benefits of argan oil: A review. Crit Rev Food 2014;54(11):1401-14.

58. Corrêa RC, Peralta RM, Bracht A, Ferreira IC. The emerging use of mycosterols in food industry along with the current trend of extended use of bioactive phytosterols. Trends FoodSci Technol. 2017; 67:19-35.

59. Bajwa HK, Nirmala C, Koul A, Bisht MS. Changes in organoleptic, physicochemical and nutritional qualities of shoots of an edible bamboo Dendrocalamus hamiltonii Nees and Arn. ex Munro during processing. JFood Process 2016;40(6):1309-1317.

60. Modgil R, Sood P. Biological protein quality of indigenous and exotic Chenopodium album (Bathua) cultivars. Int JAgric Innov Res. 2015;3(4):959-963.

\section{Figures}




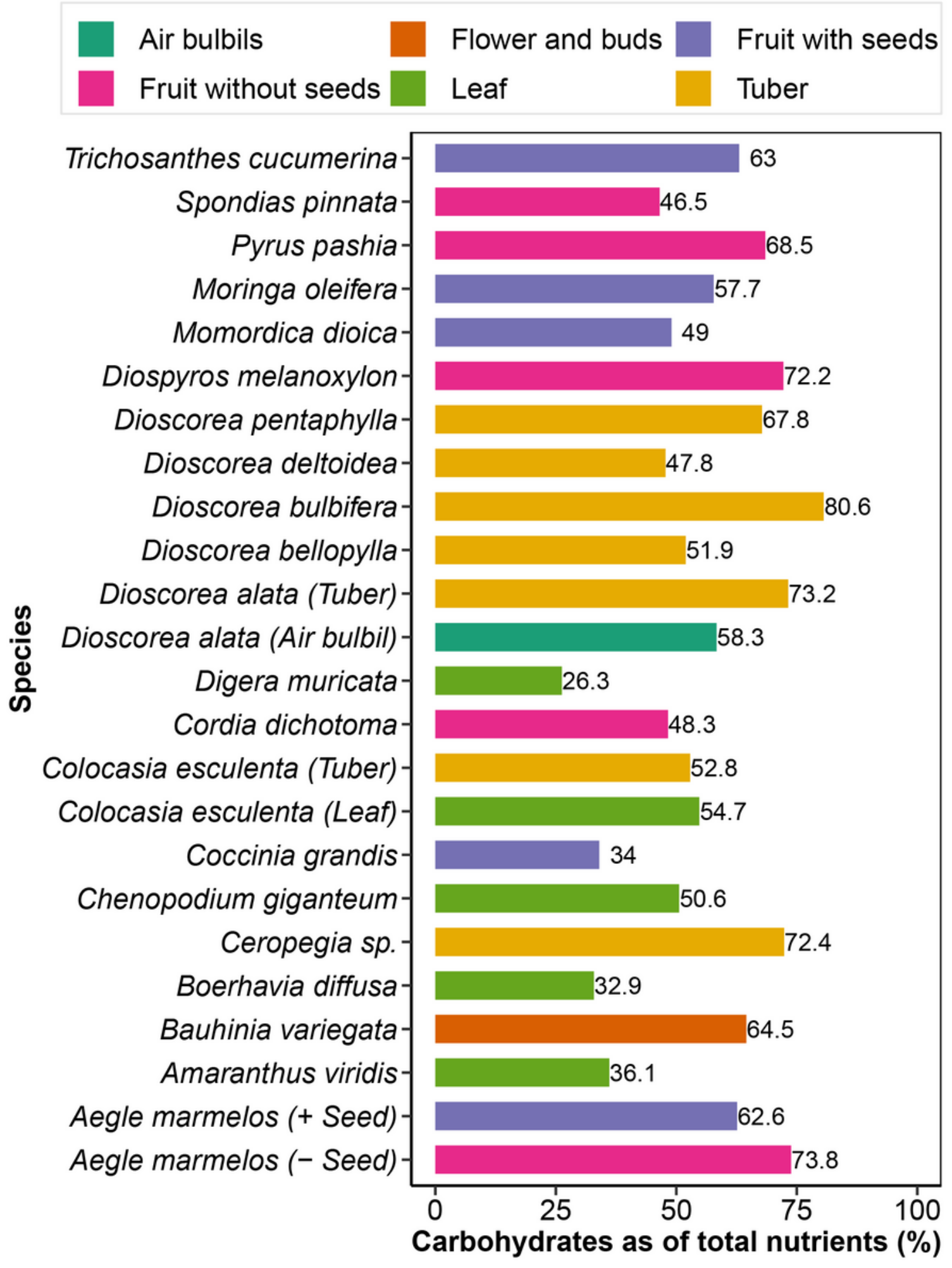

Figure 1

Fraction of carbohydrate content to the total nutrients in the selected plant species 


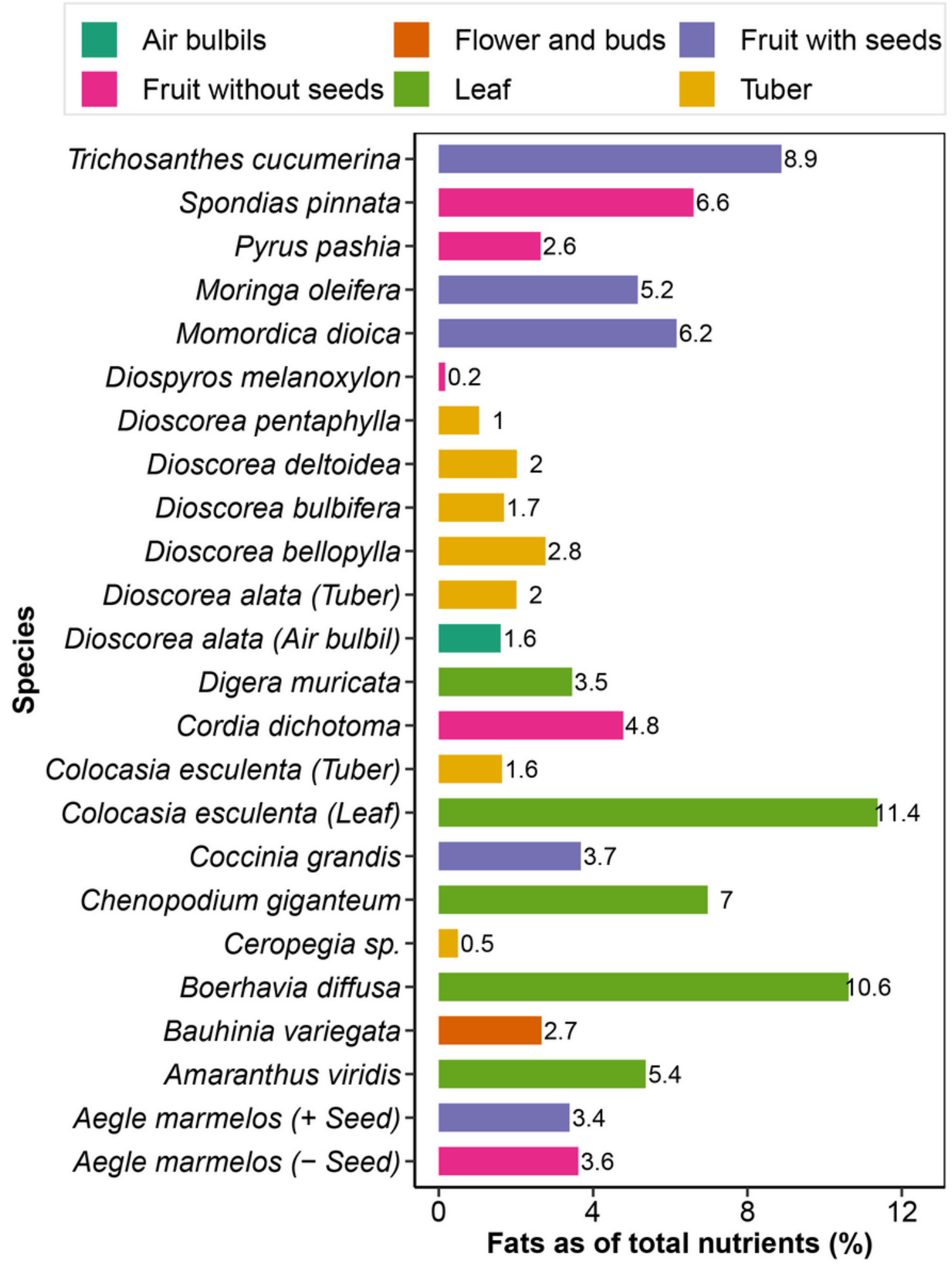

Figure 2

Fraction of fat content to the total nutrients in the selected plant species 


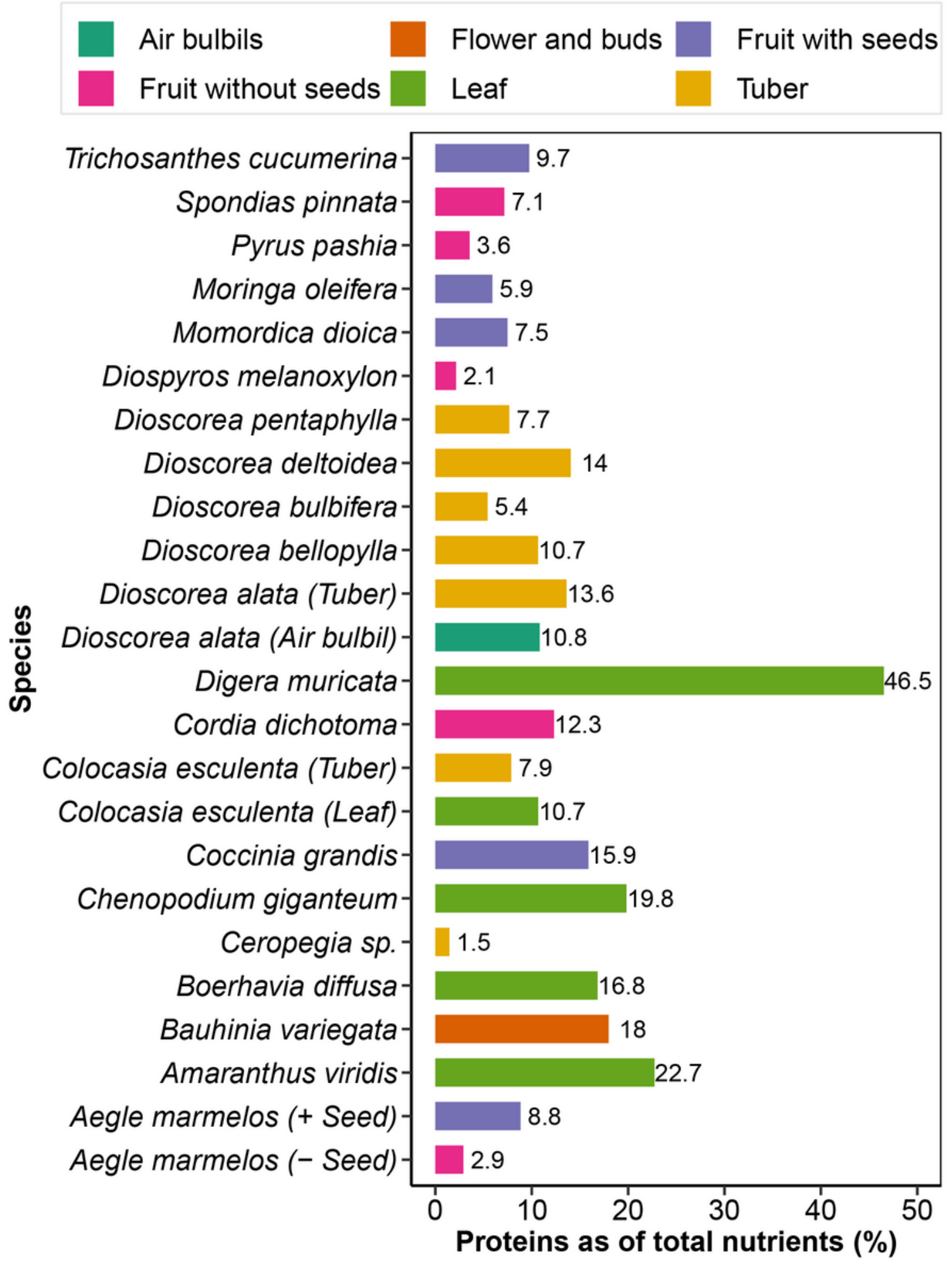

Figure 3

Fraction of protein content to the total nutrients in the selected plant species 


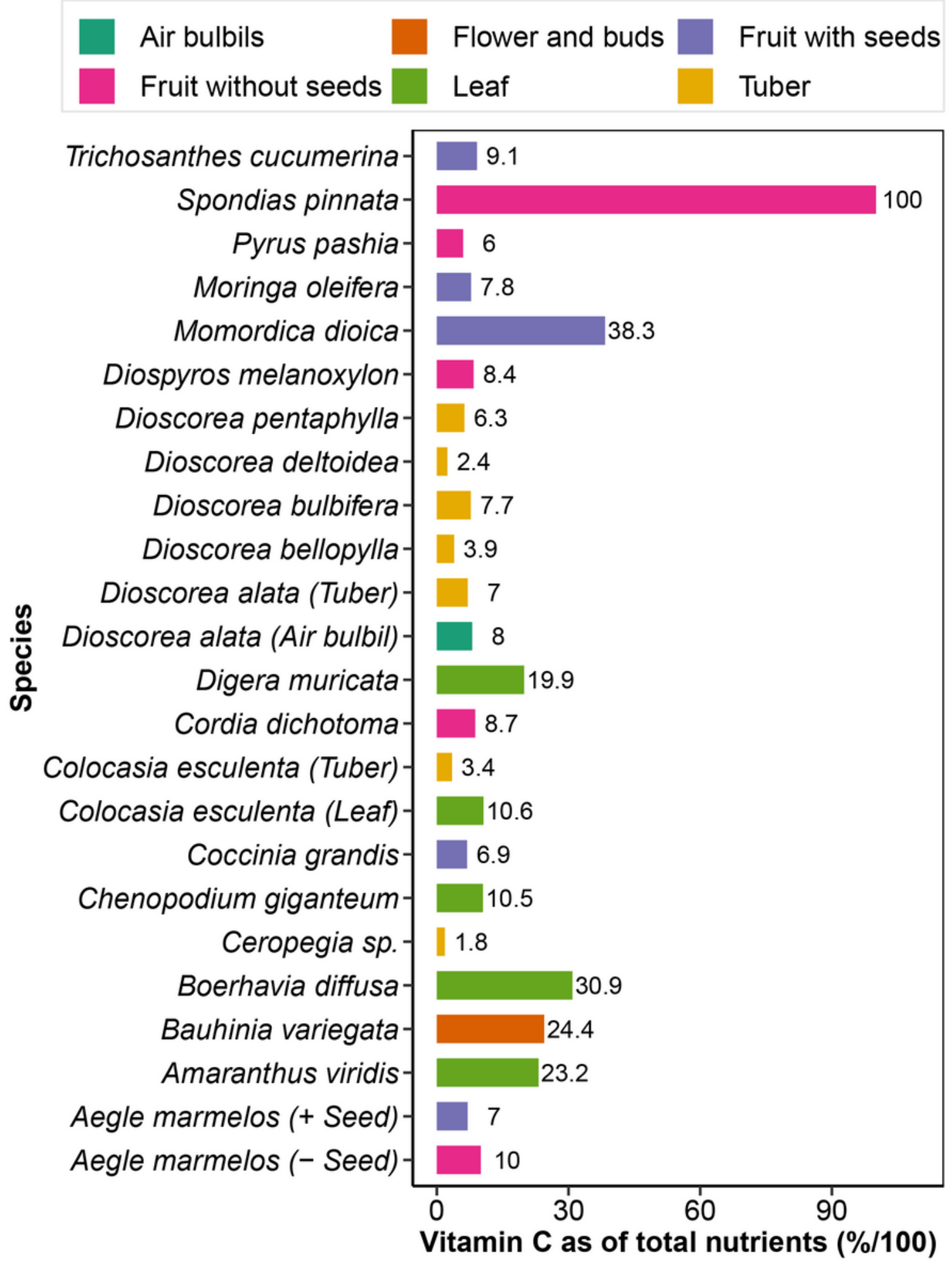

Figure 4

Fraction of Vitamin C $(\% / 100)$ content to the total nutrients in the selected plant species 


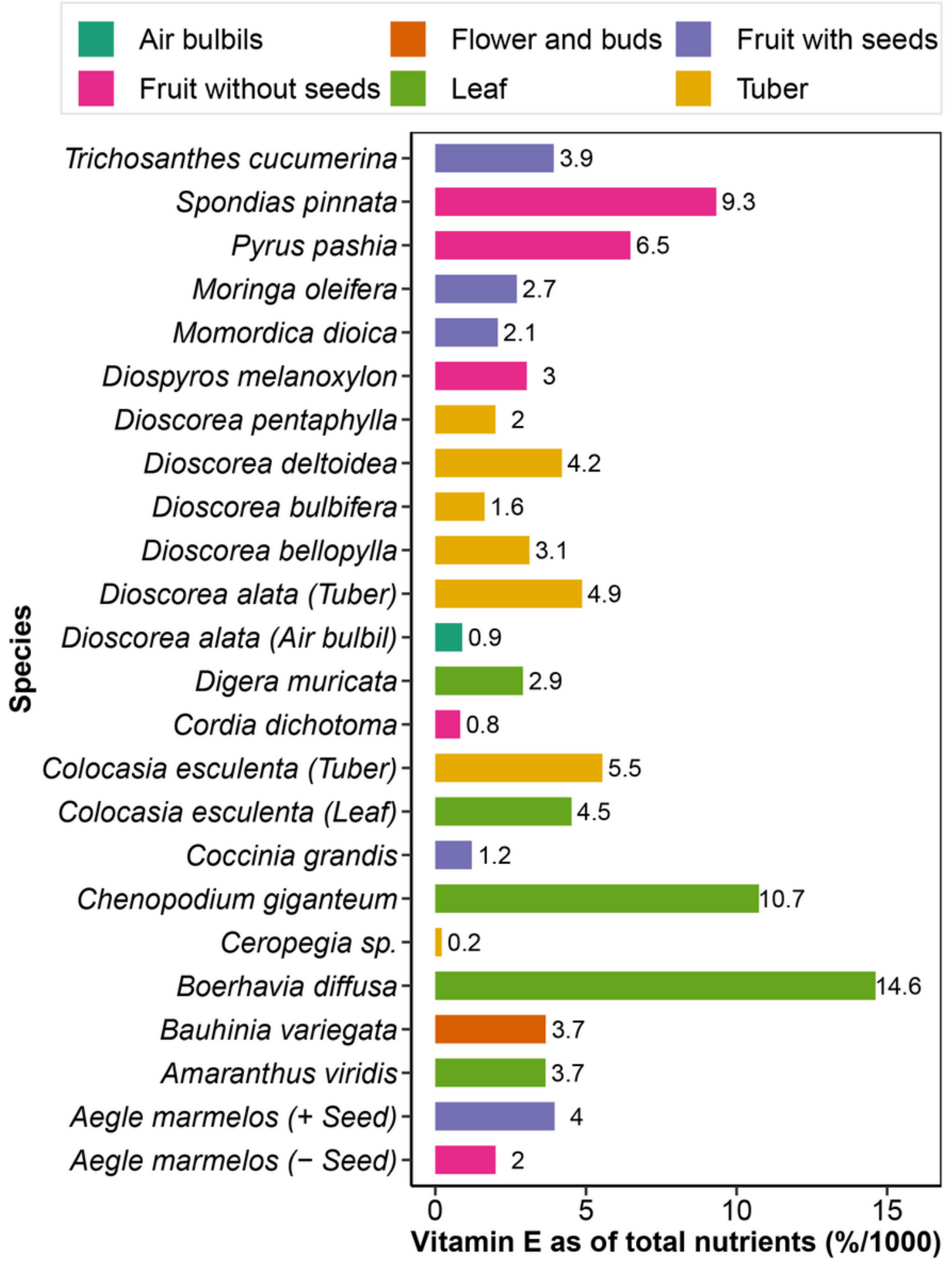

Figure 5

Fraction of Vitamin $E(\% / 1000)$ content to the total nutrients in the selected plant species 


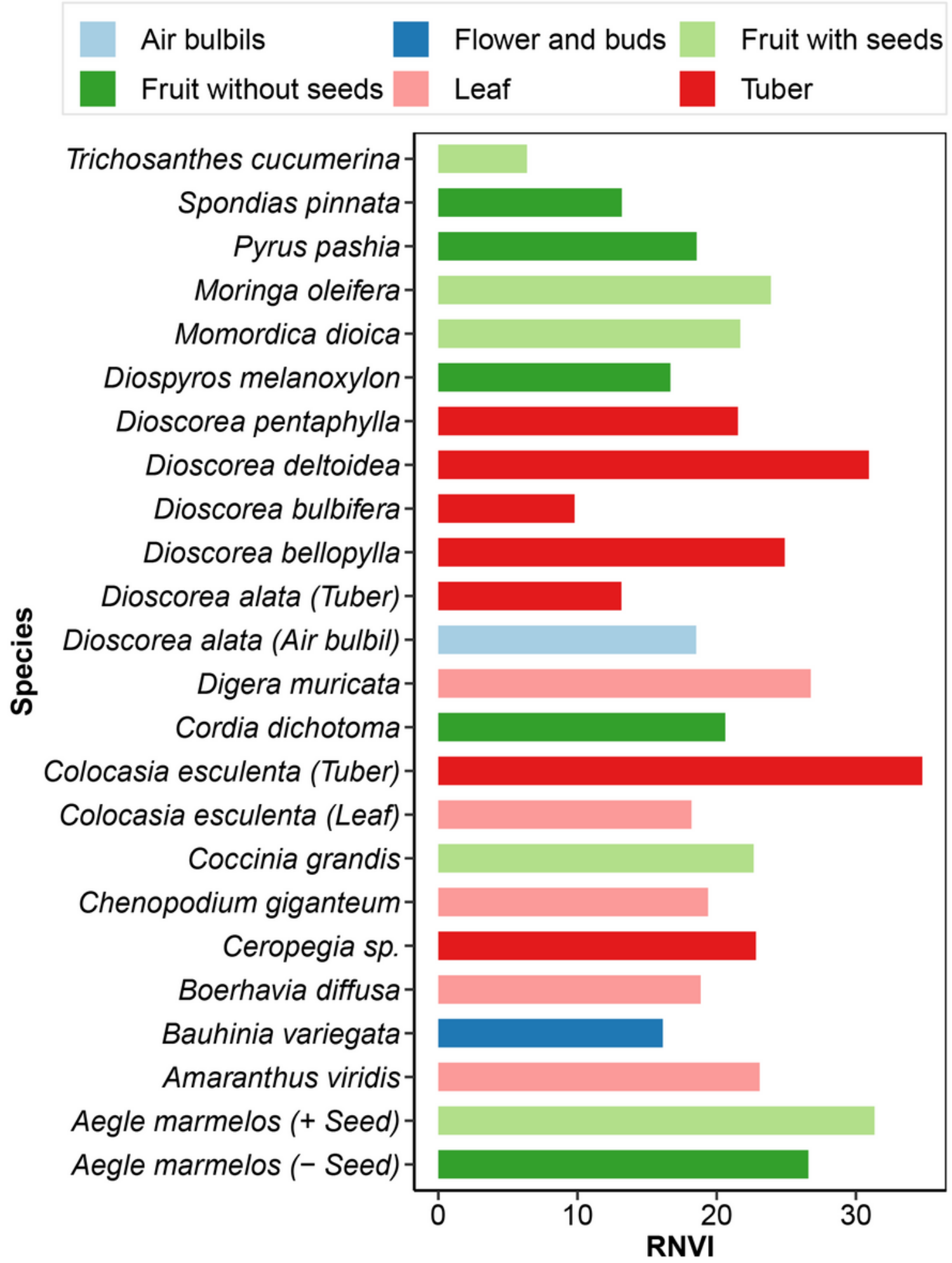

Figure 6

The relative nutrients value index (RNVI) for the selected plant species 


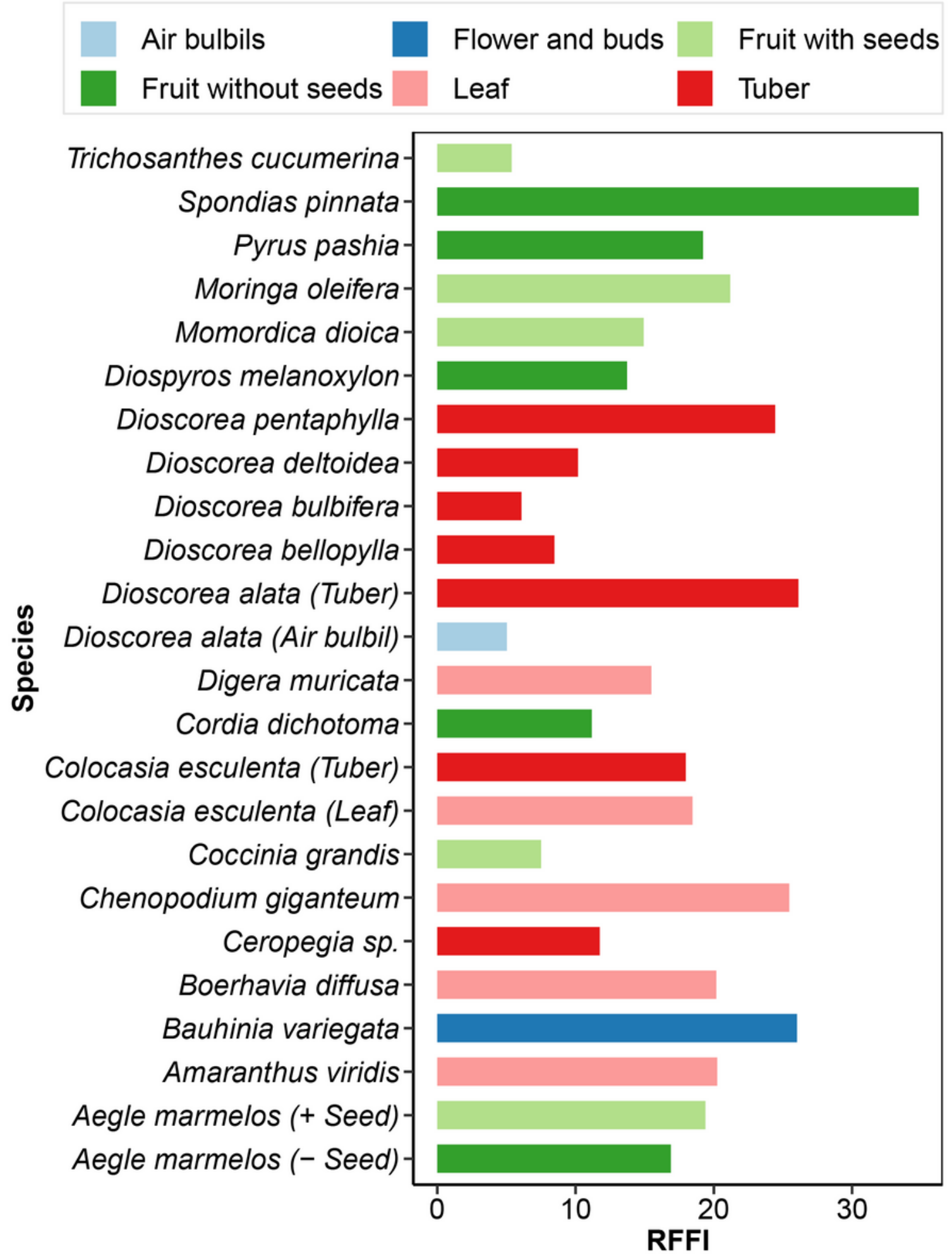

Figure 7

The relative functional food index (RFFI) for the selected plant species 


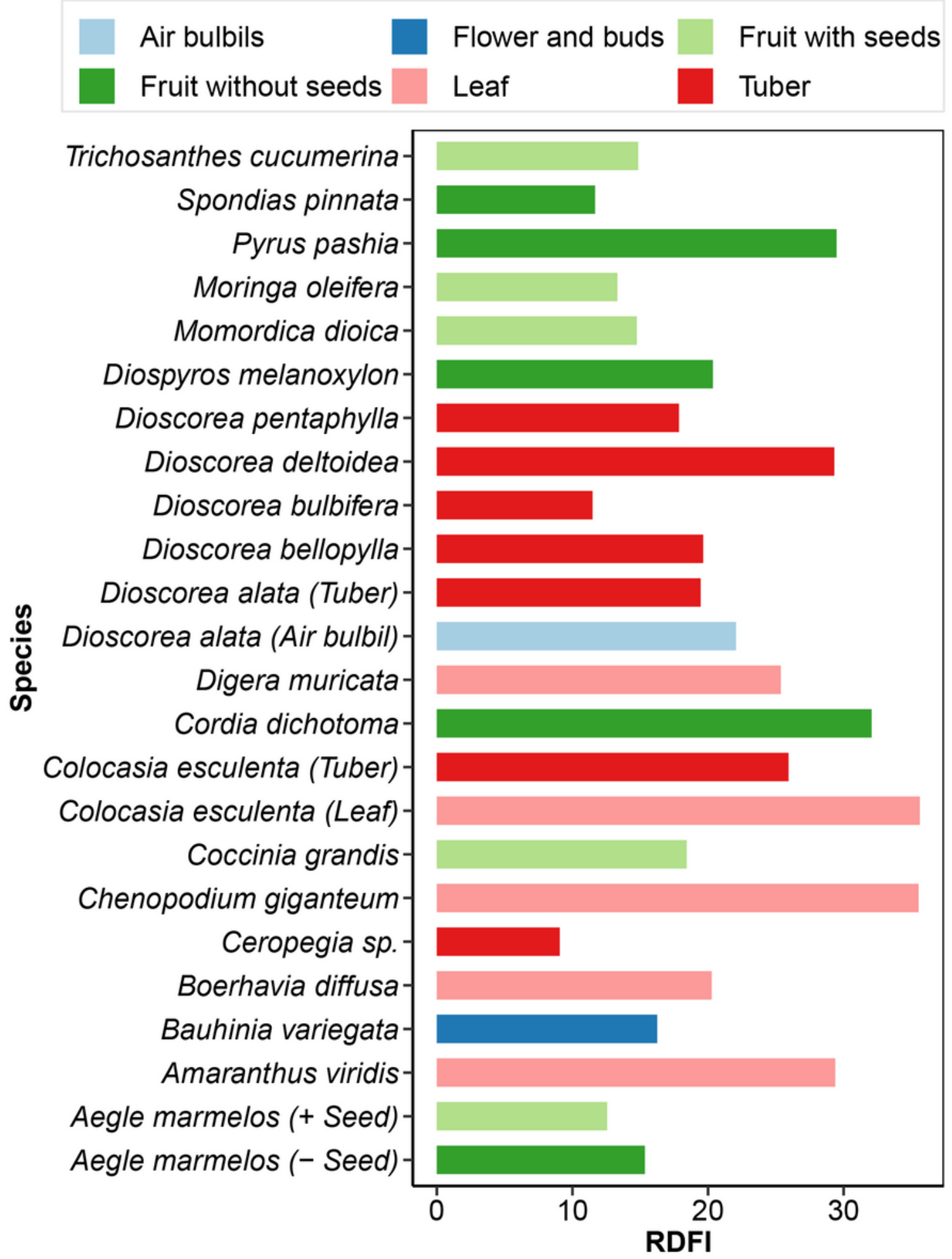

Figure 8

The relative dietary fiber index (RDFI) for the selected plant species 


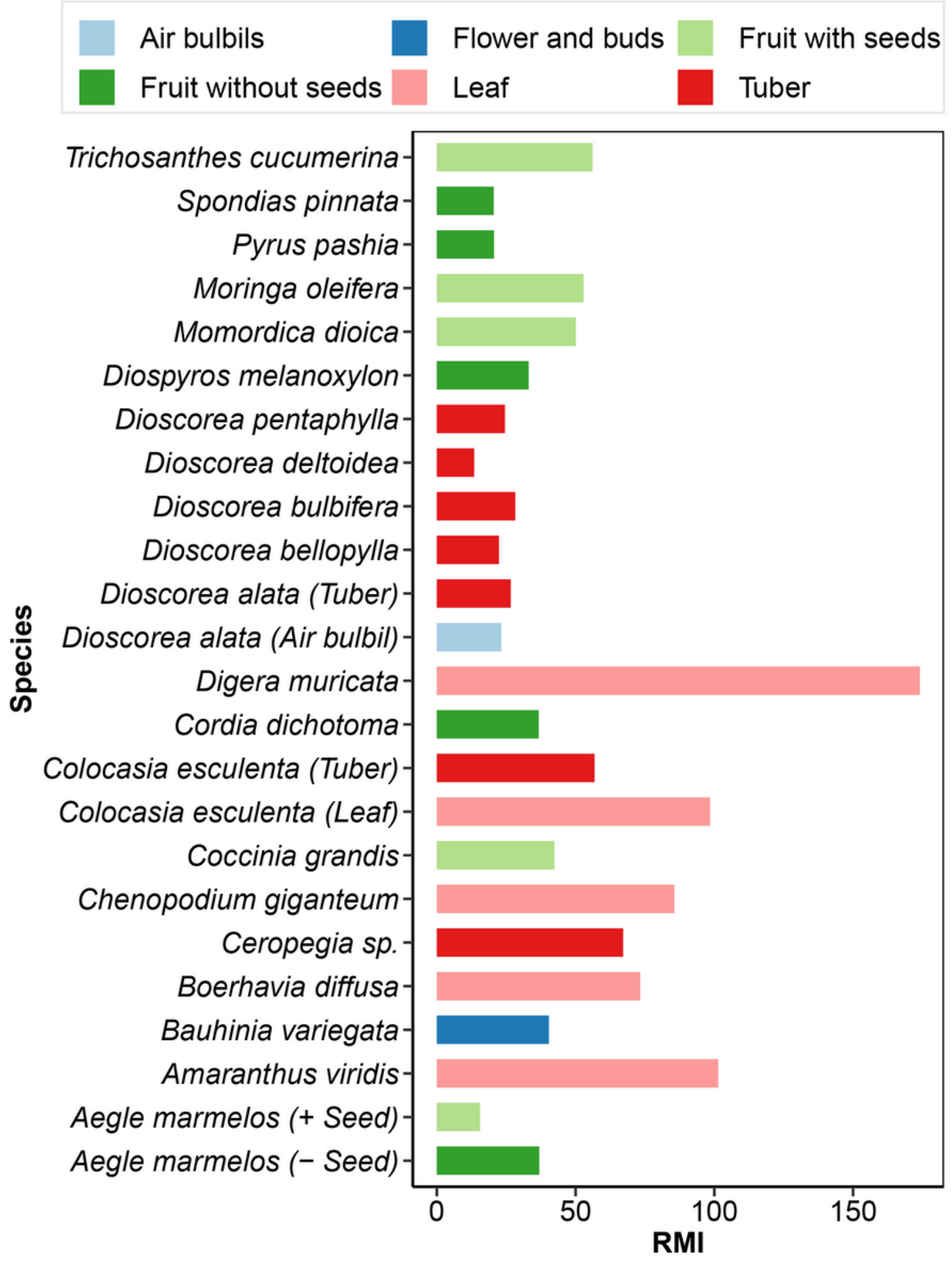

Figure 9

The relative mineral index (RMI) for the selected plant species 